\title{
The limitation of policies regarding Sportstoto: Focusing on illegal sports betting and govemment sports budget issues
}

\author{
Taeksoo Chun* \\ Hanyang University
}

\begin{abstract}
[Purpose] This study focused on analyzing the policies regarding operation of Sportstoto, a sole legal sports betting business in Korea. [Methods] In order to fulfill the research goal, literature review on reports, articles, and statistics from Ministry of Culture, Sports and Tourism, National Gambling Control Commission, Korean Sports Promotion Foundation, and other precedent studies was conducted. [Results] Currently Sportstoto fails to maintain its competitiveness due to inconvenient betting process, lack of product diversification, and low payout rate, resulting in the growth of illegal sports gambling. In addition, governmental aid for sports budget has diminished consistently, while at the same time the revenue cap regulation for betting industry restrains the development of Sportstoto and disturbs the gathering of sports budget, which appears to be a policy contradiction. Moreover, there are no specific guidelines for the expenditure of Sportstoto revenue which function as a budget. [Conclusion] This study suggests three ideas to overcome these problems. First is the alleviation of regulation in non-monetary area so that Sportstoto can improve its competitiveness against illegal sports gambling. Second is the clear establishment of policy regarding sports budget, either to foster Sportstoto as a fundraising business, or to enlarge governmental allocation for the budget. Lastly, institutional management must be provided for the expenditure of Sportstoto revenue as to follow government's sports policies.
\end{abstract}

Key words: Sportstoto, sports betting, illegal, budget, revenue cap regulation

\section{서 론}

도박의 역사는 인류의 역사와 함께 시작되었다고 해도 과언이 아니다. 도박은 시대와 지역을 불문하고 확산되어 왔다고 할 수 있다. 고대의 그리스인, 북미 지역의 인디 언, 그리고 현대 사회의 사람들까지, 인류는 다양한 시대 와 지역에 걸쳐 도박을 즐겨 왔다. Gainsbury(2010)에 따르면 실제로 고대 그리스에서 열렸던 올림픽 경기들을

논문 투고일 : 2019. 09. 30.

논문 수정일 : 2019. 11. 14

게재 확정일 : 2019. 12. 10.

* 교신저자 : 전택수(jtscj10000@ naver.com).
대상으로 베팅이 이루어졌던 역사가 있다. 비록 게임의 형태는 사회적 구조나 문화 등에 따라 각기 다른 모습으 로 존재했지만, 도박은 인간의 생활 속에서 드러나는 가 장 근본적인 특징 중 하나라고 할 수 있다(Reith, 2002). 도박의 시초는 단순한 내기를 통해 재미를 추구하는 데서 출발하였다. 역사적으로 볼 때, 우리나라에서 도박 은 전통적으로 '내기'나 '놀이', 또는 '노름' 등으로 불리며 명절 전후에 여러 사람들이 함께 재미를 위해 즐기는 일 회성 유희 문화로 인식되는 측면이 있었다(Oh et al., 2019)

도박이 사회에 미치는 영향력에 대한 의견은 긍정적. 
부정적 차원이 함께 공존해 왔다. 긍정론자들은 주로 도 박이 사회에 가져올 수 있는 기여의 측면에서 이를 긍정 적으로 평가했다. 반면 부정론자들은 인간의 내면에 잠재 해 있는 사회적 위험을 경계하는 데 초점을 맞추었다 (Vacek, 2011).

현대사회에 이르러 각종 도박은 사행산업으로 산업의 한 축을 담당하고 있다. 사행산업은 세계의 수많은 국가 들에서 각기 다른 규모와 형태로 자리잡았다. 미국의 경 우 전 세계 도박의 메카인 라스베이거스를 중심으로 카지 노 산업이 크게 발달했으며, 일본의 경우 국민 오락으로 여겨지는 파친코가 전국적인 규모로 산재해 있다.

대한민국은 국가가 인정하는 특정 사행산업을 제외한 모든 도박 행위를 원칙적으로 위법하다고 판단하고 있다. 현재 국가가 인정하고 있는 합법적 사행산업으로는 강원 랜드(카지노), 복권, 체육진흥투표권(스포츠토토), 경 마, 경륜, 경정, 소싸움 경기, 그리고 내국인이 출입할 수 없는 호텔 카지노 등이 있다. 이들은 각각의 특별법을 통 해 그 합법성을 인정받고 있다.

일반적인 도박 행위를 위법하다고 규정하고 있는 대한 민국이 합법적 사행산업을 지정하고 운영하는 이유는 앞 서 서술했듯이 도박에 대한 수요가 시대와 사회를 막론하 고 존재해 왔기 때문이다. 도박에서 오는 즐거움은 매우 강렬하며, 인간의 생리적 욕구를 유발시켜 그 몰입의 정 도가 상당하다. 도박에 대한 인간의 특성을 고려할 때 도 박을 완벽하게 사회적으로 근절하는 것은 불가능에 가깝 다. 따라서 국가가 나서서 합법적 사행산업을 운영하는 목적은, 그렇게 함으로써 사회에 존재하는 도박에 대한 수요를 흡수하고 도박 행위로 인해 발생할 수 있는 부작 용을 최소화하려는 것이라 할 수 있다(Lee, 2012).

국내 유일의 합법 스포츠도박인 체육진흥투표권의 경 우 우리나라의 스포츠 발전에 기여한다는 또 하나의 운영 목적이 존재한다. 체육진흥투표권 사업을 통해 조성된 국 민체육진흥기금은 학교체육 활성화, 생활체육 사업 지 원, 장애인 체육 단체 및 선수 지원, 각종 국제대회 지원, 스포츠산업 육성 등 대한민국의 스포츠 인프라 구축과 스 포츠 복지 확대를 위해 재투자되는 선순환 구조를 갖추고 있다. 예시로, 국민체육진흥기금은 2018 평창동계올림 픽의 성공적인 개최를 위해 약 1 조 3 천억 원의 기금을 지 원했다(Cho, 2019). 국민체육진흥기금의 대부분이 투표
권 사업의 수익금으로 조성된다는 점을 고려할 때, 체육 진흥투표권이 우리나라의 스포츠 발전에 크게 이바지한 다는 점에는 의심의 여지가 없다.

이렇듯 체육진흥투표권은 그 자체의 사업성은 물론, 인간적 본능에 의해 사회에 꾸준히 존재해온 도박 행위에 대한 욕구를 해소시켜 주며, 사업으로 얻은 수익의 대부 분이 사회로 환원되는 사회책임경영의 면모까지 모두 갖 추고 있다.

그럼에도 불구하고, 체육진흥투표권의 운영 정책에 대 한 비판의 목소리는 계속해서 끊이지 않고 있다. 이러한 비판은 대체로 사행산업 매출총량제의 실시, 불법 스포츠 도박의 횡행과 맞물려 합법 스포츠도박의 경쟁력 저하에 집중되고 있으며, 불법 스포츠도박의 사회적 폐해 증가 등으로 그 강도는 점점 높아지고 있다. $\operatorname{Kim}(2015)$ 은 합 법 도박에 대한 규제로 인해 합법시장을 불법시장에 내주 는 정책적 오류가 발생하고 있음을 지적했고, Lee \& Jo(2016)는 매출을 규제하는 사행산업 매출총량제로 인 해 불법 스포츠도박이 양산된다고 비판하였다. Lee(2018)는 체육진흥투표권이 사행성이라는 이유로 발매 제한 규제에 묶여 있는 동안 불법 스포츠도박으로 인한 각종 폐해가 더욱 커질 것을 우려하였다. $\operatorname{Moon}(2016)$ 은 과거 스포츠도박이 불법이었던 미국의 사례를 제시했는데, 대부분의 도박 사이트들이 유럽 및 중남미에 소재를 둔 반면 이들 매출의 상당량은 미국으로 부터 나왔음을 강조하며 직접적인 규제는 실효성을 가지 기 어려움을 지적하였다. 즉, 체육진흥투표권의 부족한 경쟁력이 불법 스포츠도박의 횡행을 초래했으며, 경쟁력 을 보완함으로써 불법도박과 그로 인한 부작용을 억제할 수 있다는 것이다.

불법 스포츠도박시장의 폐해를 극복하기 위해 스포츠 도박의 양성화를 이루어낸 사례로는 미국을 꼽을 수 있 다. Holden(2019)은 미국에서 스포츠도박이 합법화된 과정을 소개하였다. 미국은 1992년 프로·아마추어 스포 츠 보호법(PASPA)의 도입에 의해 대부분의 주에서 스포 츠도박이 금지되었다. 이러한 초기 배경에는 스포츠도박 이 도박 행위의 증가를 야기하고, 스포츠 경기의 본질이 경기 내용이 아닌 승부를 맞히는 것으로 바뀔 것이라는 우려가 있었다. 그러나 PASPA의 도입 이후 이에 대한 다 양한 반론이 꾸준히 제기되었다. 대표적인 반론은 바로 
스포츠도박 전면 규제가 불법 스포츠도박의 성장을 부추 겼고, 결과적으로 대부분의 도박이 불법 영역에서 발생하 게 되어 규제의 효력이 크게 감소했다는 것이다. 또한 규 제를 적용받는 합법 도박이 불법 도박보다 덜 해로우며, 합법 시장을 통한 수익 창출 및 사회 공헌 가능성 또한 대 두되었다. 이러한 주장들이 2018년 미 대법원이 PASPA 에 위헌 판결을 내리고 스포츠도박의 허용 여부를 각 주 의 재량에 맡기도록 하는 배경이 되었다고 할 수 있다.

체육진흥투표권에 대한 또 하나의 흥미로운 비판으로, 정부가 체육 재정을 마련함에 있어 예산 비중을 점점 낮 추는 한편, 투표권 사업의 수익금에 지나치게 의존하고 있다는 지적이 있다. Choi(2016)는 2000년과 2014년의 정부 예산 및 체육 부문 예산 비교를 통해 2014년 정부 예산은 2000년에 비해 약 2.65배로 증가했으나, 같은 해 체육 부문 예산은 2000 년에 비해 오히려 $17.3 \%$ 감소했 다고 주장한다. 국가가 국민 건강과 직결되는 체육 진흥 책무를 소홀히 여기고 있으며, 필요 예산을 투표권 사업 의 이익으로 갈음하고 있다는 주장이다.

체육진흥투표권에 관한 기존의 선행연구들은 주로 스 포츠도박을 포함한 사행산업 및 불법 사행산업 전반의 현 황, 체육진흥투표권 사업 자체의 경쟁력, 불법 스포츠도 박 이용자의 참여 동기, 불법 스포츠도박 문제의 해결 방 안 등에 국한되어 왔다. 불법 스포츠도박의 가파른 성장 으로 인해 도박 중독, 청소년 도박 등 각종 사회 문제들이 나타남에 따라 이에 관한 연구는 꾸준히 진행되고 있다. 그러나 체육진흥투표권의 탄생 배경에 2002 월드컵을 위 한 재원 마련이라는 분명한 목적이 있었고(Kim, 2006), 사업을 통한 수익금이 체육 예산 형성에 상당한 기여를 해왔음에도 불구하고, 투표권 사업과 정부의 체육 예산 의존도에 초점을 맞춘 선행연구는 확인할 수 없었다.

본 연구에서는 합법 스포츠도박인 체육진흥투표권에 대한 국가 정책의 실효성을 불법 스포츠도박의 횡행과 체 육 예산 의존도라는 두 가지 측면에서 재고해보고자 한 다. 현재 체육진흥투표권은 국가의 허가를 전제로 하여 상품 유형, 베팅 방법, 최대 베팅 금액 등 수많은 규제를 적용받고 있으며(Yoon, 2018), 이로 인해 불법 스포츠도 박과의 경쟁에서 밀릴 수밖에 없다는 비판이 꾸준히 제기 되고 있다. 이러한 규제들은 체육진흥투표권 사업의 시행 목적과 정면으로 배치된다고 할 수 있다. 따라서 체육진
흥투표권의 도입 취지를 명확히 분석하고, 현재 투표권 사업 운영을 둘러싼 정책적 모순과 이에 따른 사회적 부 작용들을 규명하고자 한다. 그리고 보다 효과적인 사업 운영을 통해 부작용을 최소화 하고 공익을 극대화할 수 있도록 하는 개선 방안을 정책적, 제도적 차원에서 제시 하고자 한다.

\section{연구방법}

본 연구는 체육진흥투표권 사업의 운영 목적과 이에 대한 정부 정책을 면밀히 검토하는 데 그 목적이 있는 만 큼, 연구방법으로 문헌 연구법을 채택하였다. 연구 자료 의 수집은 투표권 사업이 출범한 2001년 이후부터 현재 까지 문화체육관광부, 사행산업통합감독위원회, 국민체 육진흥공단 등 정부 기관과 사업을 주관하고 있는 (주케이 토토가 발행한 관련 보고서와 통계자료, 그리고 투표권 사업에 대해 다룬 기존의 선행연구, 언론 기사 및 간행물 등을 통해 이루어졌다.

\section{결 과}

\section{1. 체육진흥투표권 사업의 순기능과 역기능}

체육진흥투표권을 포함한 합법 사행산업은 순기능적 인 측면과 역기능적인 측면을 동시에 내포하고 있다. National Gambling Control Commission(2008)에 의 하면 사행산업의 순기능은 개인적 차원, 사회·문화적 차 원, 산업·경제적 차원으로 분류할 수 있다. 개인적 차원에 서는 사회적 욕구 해소, 레저, 심신 충전 등의 기능을 제 공한다고 보았다. 사회·문화적 차원에서는 문화 공간, 여 가 및 오락, 사회 공헌, 관련 레포츠 활동의 활성화 등의 기능을 제공한다고 보았다. 산업·경제적 차원에서는 조 세 납부를 통해 정부 및 지자체의 재정 부담을 해소하고, 지역경제 및 관련 산업의 활성화에도 직·간접적으로 기여 한다고 보았다.

한편, 합법 사행산업의 역기능으로는 도박 중독, 가족 관계 붕괴, 범죄 증가, 고용효과보다 높은 실업효과 등 병 
Table 1. Total sales of Korean gambling industry and Sportstoto from 2001 to 2008(in 100 million KRW)

\begin{tabular}{ccccccccccc}
\hline \hline & 2000 & 2001 & 2002 & 2003 & 2004 & 2005 & 2006 & 2007 & 2008 \\
\hline $\begin{array}{c}\text { Gambling industry } \\
\text { as a whole }\end{array}$ & 66,977 & 96,448 & 126,516 & 142,355 & 123,928 & 118,888 & 121,321 & 145,815 & 160,014 \\
\hline $\begin{array}{c}\text { Rate of } \\
\text { change(\%) }\end{array}$ & - & $(+44.0)$ & $(+31.2)$ & $(+12.5)$ & $(-12.9)$ & $(-4.1)$ & $(+2.0)$ & $(+20.1)$ & $(+9.7)$ \\
\hline $\begin{array}{c}\text { Sportstoto } \\
\begin{array}{c}\text { Rate of } \\
\text { change(\%) }\end{array}\end{array}$ & - & 28 & 220 & 283 & 1,389 & 4,573 & 9,131 & 13,649 & 15,962 \\
\hline \hline
\end{tabular}

Note: Retrieved from National Gambling Control Commission(2010)

리적 차원과 더불어 이로 인한 사회적 비용의 증대, 성장 잠재력 약화, 지하경제의 증가 등을 제시하였다. 사행산 업에서 비롯된 각종 부작용을 방지하기 위한 사회적 비용 의 증대가 불가피하고, 사행심리가 근로의욕을 저하시키 고 한탕주의, 요행심 등을 만연시킬 수 있으며, 합법 사행 산업의 확장은 동시에 불법 도박을 확대시킬 수 있다는 것이다.

Lee \& Jo(2016)는 자신들의 연구에서 우리나라의 스 포츠베팅 산업이 사회에 미치는 효과를 긍정적·부정적으 로 나누어 분류하였다. 먼저 긍정적인 면으로는 경제적 효과, 스포츠 기금 확보 및 활용, 건전한 여가 활용, 사행 욕구의 양성화를 제시하였다. 산업연관모델을 기반으로 분석한 Lee(2008)의 연구에 따르면 투표권 사업은 부가 가치 창출과 간접세 납부 측면에서 전체 산업의 평균보다 월등한 경제 효과를 보였다. 여기에 투표권 사업은 체육 진흥기금을 비롯한 각종 체육 사업 지원에 사용된다. 또 한 체육진흥투표권은 인간의 사행욕구를 사회 규범 내에 서 해소시켜주며, 스포츠 관람과 베팅의 결합을 통해 건 전한 여가로서의 기능을 제공한다.

한편 부정적인 효과로는 사행산업이 태생적으로 많은 문제점을 지니고 있다고 주장했다. 도박으로 인한 한탕주 의, 근로의욕 저하, 개인 파멸, 가정 파괴 외에도 도박 중 독, 승부조작, 청소년 도박 등 사회적 부작용을 심화시킬 우려가 크다고 지적했다.

종합적으로 볼 때 체육진흥투표권이 사회에 미치는 영 향은 다른 합법 사행산업과 유사하며 그 명암이 비교적 뚜렷하다. 긍정적 효과로는 사행산업을 통한 고용 증대 및 지역경제 활성화, 스포츠 발전을 위한 기금 마련, 사행
욕구 해소, 경기를 통한 여가 기능 향상 등을 들 수 있다. 반면 부정적 효과로는 단순한 부(wealth)의 이전과 제로 섬 게임 (zero sum game), 도박 중독, 근로의욕 저하, 한 탕주의 만연 등을 들 수 있다.

\section{2. 불법 스포츠도박의 실태와 추정 규모}

국내의 합법 사행산업은 점차 그 성장세가 둔화되고 있 다. 이는 과거의 급속한 성장세와 대조되는 현상으로, 사 행산업 매출총량제의 시행이 그 원인으로 꼽힌다. 사행산 업 매출총량제란 사행산업의 과도한 확산으로 인한 사회 적 부작용을 최소화하기 위해 산업의 매출 총량을 설정하 는 제도로, 사행산업통합감독위원회가 사감위법 제 16 조 에 근거해 2009년부터 실시하여 왔다(Korea Industrial Development Institute, 2011). 실제로 사행산업의 매 출 증가율은 매출총량제가 시행된 2009년을 기점으로 급 격하게 감소하는 양상을 보였다. 〈Table 1〉에 의하면 매 출총량제가 시행되기 이전인 2000년에서 2008년 동안 사행산업의 연 평균 매출 증가율은 $11.5 \%$ 에 달했다. 2001년부터 사업을 시작한 체육진흥투표권의 경우 2008 년까지 무려 $147.0 \%$ 의 연 평균 매출 증가율을 기록 했다.

한편 매출총량제가 도입된 2009년 이후 사행산업의 증가세는 완만한 형태로 전환되었다. 〈Table 2〉에 따르 면 매출총량제 시행 이후 10 년간 사행산업의 연 평균 매 출 증가율은 $3.4 \%$ 에 머물렀으며, 같은 기간 체육진흥투 표권의 연 평균 매출 증가율은 $11.7 \%$ 를 기록했다. 여전 히 체육진흥투표권이 사행산업 평균에 비해 높은 성장률 
Table 2. Total sales of Korean gambling industry and Sportstoto from 2009 to 2018(in 100 million KRW)

\begin{tabular}{|c|c|c|c|c|c|c|c|c|c|c|}
\hline & 2009 & 2010 & 2011 & 2012 & 2013 & 2014 & 2015 & 2016 & 2017 & 2018 \\
\hline $\begin{array}{l}\text { Gambling industry } \\
\text { as a whole }\end{array}$ & 165,322 & 173,270 & 183,526 & 195,443 & 196,726 & 198,933 & 205,042 & 219,777 & 217,263 & 223,904 \\
\hline $\begin{array}{c}\text { Rate of } \\
\text { change(\%) }\end{array}$ & $(+3.5)$ & $(+4.8)$ & $(+5.9)$ & $(+6.5)$ & $(+0.7)$ & $(+1.1)$ & $(+3.1)$ & $(+7.2)$ & $(-1.1)$ & $(+3.1)$ \\
\hline Sportstoto & 17,590 & 18,731 & 19,375 & 28,435 & 30,782 & 32,813 & 34,494 & 44,414 & 41,991 & 47,428 \\
\hline $\begin{array}{c}\text { Rate of } \\
\text { change(\%) }\end{array}$ & $(+10.2)$ & $(+6.5)$ & $(+3.4)$ & $(+46.8)$ & $(+8.3)$ & $(+6.6)$ & $(+5.1)$ & $(+28.8)$ & $(-5.5)$ & $(+12.9)$ \\
\hline
\end{tabular}

Note: Retrieved from National Gambling Control Commission(2019)

을 보이고 있으나, 매출총량제의 영향으로 인해 성장세가 둔화되고 있음을 확인할 수 있다.

반면 불법 스포츠도박 시장의 규모는 합법 사행산업 시장을 상회하는 것으로 추정된다. 〈Table 3〉에 의하면 불법 스포츠도박 총매출액은 2012년 제 2차 불법도박 실 태조사 시기 7조 6,103억 원, 2016년 제 3차 불법도박
실태조사 시기 21조 8,119억 원으로 드러났으며, 4년간 의 연 평균 매출 증가율은 $30.1 \%$ 을 기록했다. 같은 기간 체육진흥투표권의 총매출액은 〈Table 2〉에 드러나듯 2012년 2조 8,435억 원, 2016년 4조 4,414억 원이었으 며, 연 평균 매출 증가율은 $11.8 \%$ 이었다. 즉, 불법 스포 츠도박은 총매출액은 물론, 성장률 또한 합법 사행산업보

Table 3. Estimated value of total sales of illegal gambling market(in 100 million KRW)

\begin{tabular}{|c|c|c|c|c|c|c|}
\hline & & \multirow{2}{*}{$\begin{array}{l}1^{\text {st }} \text { investigation } \\
\text { (2008) }\end{array}$} & $\begin{array}{c}2^{\text {nd }} \text { investigation } \\
\text { (2012) }\end{array}$ & \multicolumn{3}{|c|}{$\begin{array}{c}3^{\text {rd }} \text { investigation } \\
\text { (2016) }\end{array}$} \\
\hline & & & Average & Average & Minimum & Maximum \\
\hline \multirow{4}{*}{$\begin{array}{l}\text { Online } \\
\text { gambling }\end{array}$} & Casino & \multirow{4}{*}{320,000} & 56,995 & 83,452 & 69,073 & 97,830 \\
\hline & Board games & & 85,493 & 125,177 & 103,610 & 146,745 \\
\hline & Reel slots & & 28,498 & 41,726 & 34,537 & 48,915 \\
\hline & (1) Subtotal & & 170,985 & 250,355 & 207,220 & 293,490 \\
\hline (2) Private & orts gambling & - & 76,103 & 218,119 & 180,622 & 255,615 \\
\hline (3) Illegal & ino & - & 193,165 & 62,700 & 47,328 & 78,072 \\
\hline (4) Illegal & nbling arcade & 115,596 & 187,488 & 145,152 & 134,784 & 155,520 \\
\hline \multirow{4}{*}{$\begin{array}{c}\text { Race } \\
\text { gambling }\end{array}$} & $\begin{array}{l}\text { Private horse } \\
\text { racing }\end{array}$ & 26,885 & \multirow{4}{*}{99,250} & 103,275 & 91,800 & 114,750 \\
\hline & $\begin{array}{l}\text { Private cycle } \\
\text { racing }\end{array}$ & 1,044 & & \multirow{2}{*}{24,066} & \multirow{2}{*}{21,392} & \multirow{2}{*}{26,741} \\
\hline & $\begin{array}{l}\text { Private boat } \\
\text { racing }\end{array}$ & 3,888 & & & & \\
\hline & (5) Subtotal & 31,817 & & 127,342 & 113,193 & 141,491 \\
\hline \multicolumn{2}{|c|}{ (6) Private casino } & 69,615 & 24,484 & 34,155 & 29,700 & 38,610 \\
\hline \multicolumn{2}{|c|}{ Total(1) (6)) } & 537,028 & 751,474 & 837,822 & 712,846 & 962,798 \\
\hline
\end{tabular}


다 훨씬 더 가파른 성장세를 보이고 있다.

또한 눈여겨볼 사실은 불법 스포츠도박이 불법도박 총 매출액에서 차지하는 구성비의 변화이다. 〈Table 4>에 따르면 두 번의 불법도박 실태조사가 이루어지는 동안 불 법 스포츠도박의 구성비는 2차 조사 당시인 2012년 $10.1 \%$ 에서 3차 조사 시기인 2016년 26.0\%로 크게 증가 했다. 2 차 조사 대비 변화율을 살펴보면 불법 스포츠도박 은 $186.6 \%$ 를 기록했는데, 스포츠도박을 제외한 그 어떤 항목도 $100 \%$ 가 넘는 변화율을 기록하지 못했다. 이는 불 법 스포츠도박의 증가세가 합법 사행산업은 물론, 기타 불법도박들과 비교하더라도 훨씬 가파르다는 사실을 보 여준다.

\section{3. 불법 스포츠도박의 문제점과 경쟁 우위}

불법도박은 필연적으로 많은 사회적 문제점들을 발생 시킨다. 기본적으로 불법도박은 도박 행위의 특성상 합법 사행산업이 가져올 수 있는 역기능적 요소들을 그대로 답 습한다. 도박 중독과 이로 인한 근로 의욕 저하, 가정 파 탄, 범죄 증가 등의 병리적 현상들이 대표적이라 할 수 있
다. $\operatorname{Kim}(2015)$ 은 실제로 불법 스포츠도박으로 인해 빚 을 지고, 신용불량자가 되고, 끝내 자살이라는 극단적 선 택을 행한 몇몇 사례를 제시했다.

한편으로는 합법이 아닌 불법으로 인해 추가적으로 야 기되는 문제들 또한 존재한다. 먼저 불법도박은 소득 신 고를 하지 않으므로 탈세가 가능하다. 이는 사행산업 운 영을 통한 정부의 재정 부담 해소 및 사회 공헌이라는 목 적과 정면으로 배치된다. 또한 불법도박은 계약 불이행의 위험성이 크다. 계약이 사회질서 위반으로 인정되어 무효 가 되고 이에 따라 이행을 강제하는 것이 불가능하기에, 도박의 운영 주체가 게임을 임의로 조작하거나 이익금의 환급을 거부하는 등 범죄 행위가 발생하기도 한다. 여기 에 불법도박의 참가자는 도박으로 인해 문제가 발생했을 때 사회로부터 도움을 받기가 대단히 어렵다. 불법도박 자체가 법의 테두리를 벗어나 있는 만큼 참가자는 운영 주체의 범죄 행위에 대항할 수단이 사실상 전무하다. 뿐 만 아니라 불법도박 참가자들은 도박 중독 등 각종 부작 용을 극복하고자 마음을 먹더라도, 자신의 불법 행위가 알려지는 것을 두려워해 사회의 도움을 받는 것을 스스로 포기할 우려도 있다. 마지막으로, 불법도박은 청소년 도

Table 4. Component ratio and rate of change of total sales of illegal gambling market(\%)

\begin{tabular}{|c|c|c|c|c|}
\hline & & \multicolumn{2}{|c|}{ Component rate(\%) } & \multirow{2}{*}{$\begin{array}{c}\text { Rate of change }(\%) \\
\begin{array}{c}\text { Comparison with } 2^{\text {nd }} \text { investigation } \\
\text { (Average) }\end{array}\end{array}$} \\
\hline & & $\begin{array}{l}2^{\text {nd }} \text { investigation } \\
\text { (Average) }\end{array}$ & $\begin{array}{l}3^{\text {rd }} \text { investigation } \\
\text { (Average) }\end{array}$ & \\
\hline \multirow{4}{*}{$\begin{array}{l}\text { Online } \\
\text { gambling }\end{array}$} & Casino & 7.6 & 10.0 & - \\
\hline & Board games & 11.4 & 14.9 & - \\
\hline & Reel slots & 3.8 & 5.0 & - \\
\hline & (1) Subtotal & 22.8 & 29.9 & 46.4 \\
\hline \multicolumn{2}{|c|}{ (2) Private sports gambling } & 10.1 & 26.0 & 186.6 \\
\hline \multicolumn{2}{|c|}{ (3) Illegal casino } & 25.7 & 7.5 & -67.5 \\
\hline \multicolumn{2}{|c|}{ (4) Illegal gambling arcade } & 24.9 & 17.3 & -22.6 \\
\hline \multirow{4}{*}{$\begin{array}{c}\text { Race } \\
\text { gambling }\end{array}$} & Private horse racing & \multirow{4}{*}{13.2} & 12.3 & - \\
\hline & Private cycle racing & & 29 & \\
\hline & Private boat racing & & 2.0 & 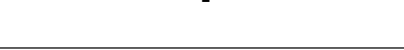 \\
\hline & (5) Subtotal & & 15.2 & 28.3 \\
\hline \multicolumn{2}{|c|}{ (6) Private casino } & 3.3 & 4.1 & 39.5 \\
\hline \multicolumn{2}{|r|}{ Total(1) 6) } & 100.0 & 100.0 & 11.5 \\
\hline
\end{tabular}

Note: Retrieved from Chungbuk National University(2016) 
박 문제를 더욱 심화시킬 수 있다. 합법 사행산업과 달리 불법도박은 신분 확인 절차가 제대로 이루어지지 않아 청 소년들도 쉽게 이용할 수 있다. 이는 불법도박 사이트들 이 복잡한 인증 없이 간단하게 접속이 가능해 청소년들의 인터넷 도박 중독을 급증시키고 있다는 $\mathrm{Oh}(2018)$ 의 주 장과도 일맥상통한다.

이러한 부작용들에도 불구, 불법 스포츠도박은 합법과 비교하여 보다 높은 경쟁력으로 이용자들을 유혹하고 있 다. 특히 불법 스포츠도박은 기술의 발달과 함께 폭발적 인 성장을 이루고 있다. 인터넷 및 모바일 환경의 발달은 불법도박 운영 주체들에게 여러 환경적인 유리함을 안겨 주었다. 이들은 더 이상 오프라인 도박장을 차리기 위해 막대한 비용을 지출할 필요가 없어졌으며, 해외를 거점으 로 온라인 불법도박 사이트를 개설함으로써 검거의 위험 성 또한 크게 낮출 수 있게 되었다. 바꾸어 말하자면 정부 입장에서는 불법도박장 운영자를 처벌하기가 더욱 어려 워진 것이다. 과거에 비해 온라인 스포츠 중계가 활성화 된 점 또한 불법 스포츠도박 사이트들에게 유리하게 작용 했다. 스포츠 경기의 중계는 프로스포츠 시장의 성장과 더불어 온라인·모바일 환경에서 활발하게 보급되고 있는 데, 이는 경마·경정·경륜 등의 중계가 매우 제한적으로 이 루어지고 있는 점과 대조된다. 이에 따라 불법 스포츠도 박 운영자들은 수많은 스포츠 중계들을 자신들의 사이트 를 통해 손쉽게 제공하며 잠재적 도박자들을 유혹하고 있 다. 여기에 그치지 않고 불법 스포츠도박 사이트들은 불 법 웹툰, 음란 사이트 등과 연계하여 광고를 내거는 등 고 객 유치에도 적극적으로 나서고 있다(Park, 2019).

도박 참가자의 입장에서도 모바일 환경의 발달에 따라 불법도박에 대한 접근성이 개선되며 참가 유인이 크게 증 가하였는데, 이는 합법 사행산업들이 각종 규제로 인해 인터넷·모바일 시장 구축에 어려움을 겪고 있기 때문이 다. 이러한 현상은 합법 사행산업이 정보통신기술의 비약 적 발전에 제대로 대응하지 못하고 있다는 Kang(2015) 의 지적과도 일치한다. Yun(2016)의 연구에 따르면 불 법 스포츠도박 사이트 중 $82.5 \%$ 에서 스마트폰을 통한 베 팅이 가능했다. 반면 체육진흥투표권은 스마트폰을 통한 사이트 접속은 가능하나, 베팅은 불가능하다. 모바일 어 플리케이션의 경우도 현재 시중에 스포츠도박과 관련된 수많은 모바일 어플리케이션들이 존재하고 있는 데 비해,
체육진흥투표권은 어떠한 모바일 어플리케이션도 제공 하지 못하고 있다.

도박 참가자들이 합법인 체육진흥투표권 대신 불법 스 포츠도박을 선택하는 동기에 대해서는 다양한 선행연구 가 이루어지고 있다. Lim et al. (2014)은 불법 스포츠도 박 참가자들의 이용 행태에 관한 연구에서 이들의 참가 동기로 높은 배당률, 간편한 베팅 방법, 상품 종목의 다양 성 등을 강조하였다. Lee \& Hong(2017)은 소비자들이 불법도박을 선택하는 이유로 베팅의 편의성, 단순한 게임 유형, 편리한 접근성 등을 제시하였으며, 이와 더불어 해 외의 합법 스포츠도박 사이트들이 안전성과 합법성, 합리 적 배당률 등을 통해 국내 소비자들을 유인하고 있다고 밝혔다. Lee et al(2018)는 합법 사행산업과 불법도박의 대체 관계에 대한 연구에서 불법 스포츠도박 참가동기로 접근의 용이성, 구매시간 무제한, 신속한 환급 등을 제시 하였으며, 이러한 요소들의 부재로 인해 불법 스포츠도박 에 대한 체육진흥투표권의 대체 관계가 약하게 나타나고 있다고 강조했다. Yoon(2018)은 불법 스포츠도박이 체 육진흥투표권과 비교하여 베팅 방식의 편의성, 높은 환급 률, 베팅 금액의 무제한성, 다양한 상품, 익명성 등에서 소비자들을 끌어들이고 있다고 언급하였다.

특정 집단을 대상으로 한 불법 스포츠도박 참가 동기 에 대한 선행연구 또한 다양하게 이루어졌다. Kim et $\mathrm{al}(2016)$ 는 대학생들을 대상으로 한 연구에서 이들의 불 법도박 참가 동기로 경계심 부족, 준법정신 부족, 합법 스 포츠토토에 대한 불만, 그리고 불법 스포츠도박의 베팅 환경에 대한 긍정적 평가를 제시하였다. $\mathrm{Kim} \&$ $\mathrm{Oh}$ (2017)는 남자 중·고등학생의 불법 스포츠도박 실태 에 대한 연구에서 불법 스포츠도박을 경험한 학생들이 그 렇지 않은 학생들에 비해 금전 동기가 높았음을 강조하였 다. 한국의 엘리트스포츠 선수들의 불법 스포츠도박 참여 동기에 대한 연구 또한 이루어졌는데, 이들이 처음 불법 스포츠도박에 참가하는 이유로는 준거집단의 영향과 승 률에 대한 자신감이, 불법 스포츠도박 행동을 지속하는 이유로는 스트레스 해소와 재미, 본전에 대한 생각이 제 시되었다(Kwon \& Lee, 2018).

정리하자면, 체육진흥투표권 대신 불법 스포츠도박을 이용하는 참가자의 동기는 크게 금전적 동기와 비금전적 동기로 분류할 수 있다. 금전적 동기로는 높은 환급률이 
제시되었다. 이는 체육진흥투표권의 환급률이 $60 \%$ 에 불 과한 데 비해, 불법 스포츠도박 업체들의 환급률이 80 90\%로 추정되고, 해외 사설 스포츠베팅 업체들의 환급률은 90\%를 상회한다는 Han \& Kang(2012)의 연 구에서 구체적으로 제시한다. 비금전적 동기로는 베팅의 편의성과 상품의 다양성 등이 공통적으로 제시되었다. 현 재 체육진흥투표권의 구입은 컴퓨터를 통한 온라인 환경 에서만 가능하다. 스마트폰을 이용할 경우 사이트 접속만 가능할 뿐 베팅은 불가능하며, 모바일 어플리케이션은 제 공되지 않고 있다. 베팅이 허용되는 시간 또한 08:00 22:00로 제한되어 있어 새벽에 펼쳐지는 해외 스포츠 경 기들과의 연계 효과가 떨어진다. 여기에 프로토 상품의 경우 단일 경기 베팅은 불가능하며, 2 경기 이상을 조합해 야만 베팅이 가능해 이용자들의 부담을 증가시킨다. 또한 현재 체육진흥투표권이 제공하는 상품들은 승패 및 스코 어 차이를 맞추는 유형에만 국한되어 있다. 반면 사설 스 포츠도박 업체들은 첫 삼진, 첫 3점슛 성공 등 세분화된 수많은 유형의 상품들을 제공하고 있다. 즉, 체육진흥투 표권의 부족한 상품 다양성이 보다 단순하고 즉흥적인 유 흥을 원하는 수요자들의 사행 욕구를 충족시켜주지 못하 고 있는 것이다. 이는 일부 도박 참가자들이 베팅 과정에 서 경기를 분석하거나, 승패가 결정되기까지 기다리지 않 아도 되는 베팅 상품들을 선호한다는 Lee \& Hong(2017)의 연구를 통해 뒷받침된다.

상기한 자료를 모두 고려할 때, 불법 스포츠도박은 체 육진흥투표권에 대해 확실한 경쟁 우위를 확보하고 있다. 불법 스포츠도박은 베팅 환경, 상품의 다양성, 환급률 등 여러 측면에서 체육진흥투표권보다 유리하다. 이를 바탕 으로 불법 스포츠도박의 총매출액 규모는 체육진흥투표 권의 약 5 배에 달했으며, 증가율도 체육진흥투표권보다 훨씬 높았다. 다시 말해, 체육진흥투표권의 사업 경쟁력 은 불법 스포츠도박에 미치지 못하고 있으며, 자연스럽게 사회 내 존재하는 도박 수요를 제대로 흡수하지 못해 합 법 사행산업으로서 사회에 제공할 수 있는 편익이 상당히 제한되고 있는 것으로 볼 수 있다.

\section{4. 국민체육진흥기금과 체육 예산 의존도}

체육진흥투표권은 국민체육진흥법에 의거, 국가정책
사업으로서 2001년 10월 공식 출범하였다. 당시 투표권 사업의 출범 배경에는 2002년 한일 월드컵의 성공적인 개최와 향후 국민체육 육성 등을 위한 재원 조성이라는 뚜렷한 목적이 있었다. 국민체육진흥법 제 29조는 체육 진흥투표권 사업의 총매출액 중 환급금과 위탁 운영비를 제외한 금액은 국민체육진흥공단에 넘겨주어야 하며, 공 단은 이를 국민체육진흥계정에 출연하고 그 결과를 문화 체 육관광부 장관에게 보고해야 함을 명시하고 있다. 이에 따라 투표권 사업의 수익금 중 대부분은 국민체육진흥기 금으로 편입되어 국민체육 및 대한민국 스포츠 발전을 위 해 사용되어 왔으며, 이 외에도 경기 주최 단체, 문화체육 산업, 월드컵 등 국제대회 조직위원회, 월드컵 경기장 건 립비, 공공체육시설 개·보수 등을 지원하기 위해 분배되 어 왔다.

체육진흥투표권은 사업 운영을 통해 체육 예산 조성에 기여한다는 점에서 기타 합법 사행산업과는 차별화된다 고 할 수 있다. 현재 우리나라의 체육 예산은 정부 예산과 국민체육진흥기금으로 구성되며, 이 중 국민체육진흥기 금은 체육진흥투표권 사업의 출연금, 경륜·경정 사업의 수익금, 복권 및 복권기금법에 의한 복권수입금, 기금 운 용으로 발생하는 수익금, 회원제 골프장 입장료에 대한 부가금, 그리고 문화체육관광부 장관이 승인하는 광고사 업의 수입금 등을 통해 조성되고 있다.1)

체육진흥투표권은 국민체육진흥기금의 조성에 상당한 기여를 하고 있다. 지난 5 년간 국민체 육진흥기금 총 조성 액 중 체육진흥투표권 수익금이 차지하는 비중은 〈Table $5>$ 와 같았다. 5년 동안 전체 기금 조성액 대비 투표권 사 업 수익금의 비율이 $80 \%$ 이상을 차지할 정도로 투표권 사업은 기금 조성에 핵심적인 역할을 수행해 왔다.

체육 예산에서 국민체육진흥기금이 차지하는 중요성 은 〈Table 6〉와 〈Figure 1〉에 나타나듯 꾸준히 증가해 왔 다. 전체 예산 중 국민체육진흥기금의 구성비는 2008년 $55.9 \%$ 를 기록한 이래 급격한 상승세를 보였으며, 가장 높았던 2016년에는 무려 전체 예산 중 $91.2 \%$ 를 부담했 다. 2016년을 기점으로 전체 예산 대비 기금의 비율은 완 만한 하락세를 보이고 있으나, 여전히 2011년 이후 단 한 번도 $80 \%$ 이하로 내려간 적이 없었다.

1) 전체 체육 재정에는 각 지방자치단체의 지원금 또한 포함되나, 여기서는 기획재정부가 발표하는 체육 예산만을 고려하였음. 
Table 5. National Sports Promotional Funds from 2014 to 2018(in 100 million KRW)

\begin{tabular}{|c|c|c|c|c|c|}
\hline & 2014 & 2015 & 2016 & 2017 & 2018 \\
\hline Total & 12,294 & 13,262 & 14,190 & 15,767 & 16,546 \\
\hline Private Contribution & 0 & 0 & 0 & 0 & 0 \\
\hline Golf course revenue & 440 & 467 & 450 & 434 & 399 \\
\hline Corporate revenue & 10,705 & 11,686 & 12,479 & 13,520 & 14,538 \\
\hline - Cycle racing & 218 & 412 & 337 & 288 & 220 \\
\hline - Boat racing & 37 & 80 & 72 & 56 & 31 \\
\hline - Sportstoto & $\begin{array}{c}10,450 \\
\mathbf{( 8 5 . 0 \% )}\end{array}$ & $\begin{array}{c}11,194 \\
\mathbf{( 8 4 . 4 \% )}\end{array}$ & $\begin{array}{c}12,070 \\
\mathbf{( 8 5 . 1 \% )}\end{array}$ & $\begin{array}{c}13,176 \\
\mathbf{( 8 3 . 6 \% )}\end{array}$ & $\begin{array}{c}14,287 \\
\mathbf{( 8 6 . 3 \% )}\end{array}$ \\
\hline Lottery revenue & 529 & 528 & 534 & 629 & 683 \\
\hline Investment revenue & 374 & 209 & 517 & 222 & 235 \\
\hline Interest revenue & 71 & 61 & 71 & 69 & 138 \\
\hline The others & 175 & 311 & 139 & 893 & 553 \\
\hline
\end{tabular}

Note: Retrieved from Korean Sports Promotion Foundation

Table 6. Annual sports budget and its component ratio from 2005 to 2019(in 100 million KRW)

\begin{tabular}{|c|c|c|c|c|c|}
\hline & \multicolumn{2}{|c|}{ Governmental aid } & \multicolumn{2}{|c|}{ National Sports Promotion Funds } & \multirow{2}{*}{ Total sports budget } \\
\hline & Amounts & Component ratio(\%) & Amounts & Component ratio(\%) & \\
\hline 2005 & 1,137 & 27.8 & 2,948 & 72.2 & 4,085 \\
\hline 2006 & 1,487 & 36.4 & 2,603 & 63.6 & 4,090 \\
\hline 2007 & 1,812 & 41.0 & 2,608 & 59.0 & 4,419 \\
\hline 2008 & 2,341 & 44.1 & 2,963 & 55.9 & 5,304 \\
\hline 2009 & 2,133 & 34.5 & 4,043 & 65.5 & 6,175 \\
\hline 2010 & 1,527 & 20.9 & 5,776 & 79.1 & 7,303 \\
\hline 2011 & 1,556 & 18.5 & 6,846 & 81.5 & 8,403 \\
\hline 2012 & 1,514 & 17.5 & 7,120 & 82.5 & 8,634 \\
\hline 2013 & 1,715 & 16.0 & 9,029 & 84.0 & 10,744 \\
\hline 2014 & 1,486 & 14.2 & 8,977 & 85.8 & 10,463 \\
\hline 2015 & 1,342 & 9.9 & 12,199 & 90.1 & 13,541 \\
\hline 2016 & 1,355 & 8.8 & 14,031 & 91.2 & 15,386 \\
\hline 2017 & 1,337 & 8.9 & 13,684 & 91.1 & 15,021 \\
\hline 2018 & 1,287 & 10.9 & 10,564 & 89.1 & 11,850 \\
\hline 2019 & 2,368 & 16.2 & 12,275 & 83.8 & 14,643 \\
\hline
\end{tabular}

Note: Reanalyzed data from Ministry of Culture, Sports and Tourism 


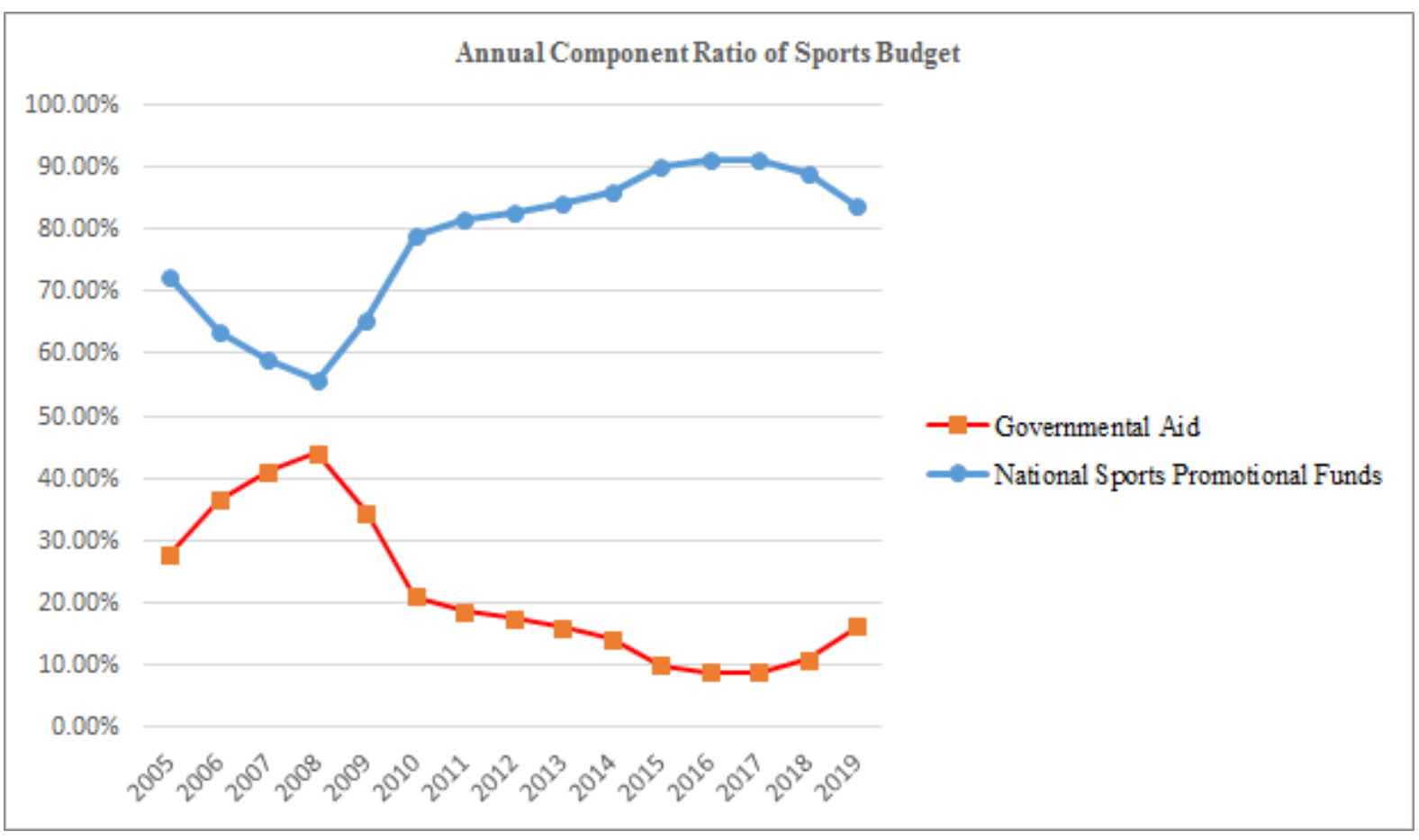

Figure 1. Annual component ratio of sports budget

이렇듯 체육진흥투표권이 전체 체육 예산에서 차지하 는 중요성은 막중하다고 할 수 있다. 현재 우리나라의 체 육 예산은 그 구성에 있어 대부분을 국민체육진흥기금에 의존하는 구조이며, 국민체육진흥기금은 체육진흥투표 권의 수익금에 크게 기대고 있다. 즉, 투표권 사업은 공공 재정 기여라는 형태로 대한민국의 체육 발전에 크게 이바 지하고 있는 것이다.

동시에 이는 정부의 체육 분야에 대한 예산 지원이 시 간이 갈수록 빈약해지고 있다는 반증이기도 하다. 〈Table 7〉에서 드러나듯 2008년을 기점으로 정부 총예 산 대비 체육 예산 지원금의 비율은 2013년과 2019년을 제외하고는 계속해서 감소했다. 금액 자체를 놓고 보더라 도 정부 총예산은 지속적으로 증가한 반면, 체육 예산 지 원금은 꾸준히 완만한 감소세를 보였다. 그나마 2019년 체육 예산 지원금이 큰 폭으로 늘어난 사실은 2008년 이 후 계속해서 감소한 체육 분야에 대한 지원 문제를 개선 하려는 정부의 의지가 미약하게나마 반영된 것으로 해석 할 수 있다.
Table 7. Annual budget of Korea and governmental aid for sports budget

\begin{tabular}{lccc}
\hline \hline & $\begin{array}{c}\text { Total budget } \\
(1,000 \text { billion } \\
\text { KRW })\end{array}$ & $\begin{array}{c}\text { Aid for } \\
\text { sports budget } \\
(100 \text { million } \\
\text { KRW })\end{array}$ & Ratio(\%) \\
\hline 2005 & 207.8 & 1,137 & 0.055 \\
\hline 2006 & 222.0 & 1,487 & 0.067 \\
\hline 2007 & 237.1 & 1,812 & 0.076 \\
\hline 2008 & 257.2 & 2,341 & 0.091 \\
\hline 2009 & 284.5 & 2,133 & 0.075 \\
\hline 2010 & 292.8 & 1,527 & 0.052 \\
\hline 2011 & 309.1 & 1,556 & 0.050 \\
\hline 2012 & 325.4 & 1,514 & 0.047 \\
\hline 2013 & 342.0 & 1,715 & 0.050 \\
\hline 2014 & 355.8 & 1,486 & 0.042 \\
\hline 2015 & 375.4 & 1,342 & 0.036 \\
\hline 2016 & 386.4 & 1,355 & 0.035 \\
\hline 2017 & 400.5 & 1,337 & 0.033 \\
\hline 2018 & 428.8 & 1,287 & 0.030 \\
\hline 2019 & 469.6 & 2,368 & 0.050 \\
\hline \hline
\end{tabular}

Note: Reanalyzed data from Ministry of Economy and Finance 
그런데 체육진흥투표권의 체육 예산 활용은 투표권 사 업의 성장을 옥죄고 있는 매출총량제의 시행과 정면으로 충돌하게 된다. 현재 우리나라의 체육 예산에서 투표권 사업이 차지하는 중요성은 대단히 크다. 정부는 체육 분 야에 대한 국고 지원금을 꾸준히 줄이는 한편 투표권 사 업 수익금을 통해 부족한 예산을 갈음해 왔다. 그러나 동 시에 시행되고 있는 매출총량제의 존재는 예산 조성이라 는 체육진흥투표권의 순기능을 억제하고 있다. 즉, 정부 는 체육 분야에 대한 지원이 미흡함은 물론, 이를 보완하 기 위한 투표권 사업의 운영에도 스스로 규제를 통해 굴 레를 채우고 있는 셈이다.

체육진흥투표권의 체육 예산 활용에 있어, 수익금을 체육진흥 목적으로 올바르게 사용하기 위한 정부의 가이 드라인이 제대로 갖추어지지 않고 있다는 또 다른 문제가 있다. 앞서 나타났듯 현재 우리나라의 체육 예산은 국민 체육진흥기금의 주요 수입원인 투표권 사업 수익금에 크 게 의존하고 있는 상황이다. 체 육진흥투표권의 출범 배경 에는 생활체육 활성화와 국민체육 진흥을 위한 공공재원 마련이라는 목적이 있었던 만큼, 사업의 수익금이 체육 예산으로 사용되는 것 자체에는 큰 문제가 없다. 중요한 것은 공공재원으로서 각 단체들에 지원되는 국민체육진 흥기금의 사용에 대한 정부 지침이 전무하다는 사실이다.

문화체육관광부는 사업비 집행규정을 통해 체육진흥 투표권 발행 대상 운동경기를 주최하는 단체와 비발행 대 상 종목 육성을 위해 지원되는 기금의 집행 대상, 분배 기 준, 사후 관리 등에 관한 사항을 규정하고 있다. 그러나 이러한 규정은 프로스포츠 활성화 사업, 아마추어 스포츠 활성화 사업 등 피상적인 설명 수준에 그치고 있다. 기금 의 세부 사용처에 대한 권고나 제한은 찾아볼 수 없으며, 집행 과정에 대한 감시 또한 전혀 없다고 봐도 무방하다. 사후 관리 차원에서 지원금 사용 실태 조사나 성과 평가 등을 실시할 수 있으나, 이는 기금의 집행이 모두 끝난 뒤 에야 이루어지게 된다.

실제로 국민체육진흥기금의 운동경기 주최단체 지원 금 사용과 관련된 논란이 발생한 적이 있다. 2015년 K리 그와 $\mathrm{KBS}$ 는 15 억 원 규모의 텔레비전 중계권료 계약을 맺었고, 해당 계약에 의해 $\mathrm{KBS}$ 는 한 시즌 최대 20 회의 K 리그 클래식 경기를 생중계하기로 되어 있었다. 그런데 여기에는 KBS가 K리그 클래식 한 경기를 생중계할 때마
다 $\mathrm{K}$ 리그가 1 억 원의 제작비를 $\mathrm{KBS}$ 에 지원한다는 세부 조항이 포함되어 있었다. $\mathrm{KBS}$ 입장에서는 수익성 면에 서 당시 인기가 떨어졌던 $\mathrm{K}$ 리그 경기를 중계하는 것보다 같은 시간 다른 프로그램들을 방영하는 것이 나았기에 경 기 중계에 미지근한 반응을 보였고, 이에 $\mathrm{K}$ 리그가 생중 계 확보를 위해 최후의 수단으로 제작비 지원 카드를 꺼 내든 것이다. $\mathrm{K}$ 리그는 프로축구의 흥행을 위해 초기 미 국의 메이저리그 사커(MLS)가 방송 중계를 확보하기 위 해 썼던 계약 방식을 벤치마킹했다고 밝혔다(Kim, 2015). 결과적으로 이는 생활체육 및 국민체육 진흥이라 는 체육진흥투표권 및 국민체육진흥기금의 본래 취지와 크게 어긋나는 모습으로 이어졌다.2) 그리고 이러한 계약 이 가능했던 본질적인 이유는 결국 지원 기금의 사용에 대한 세부 지침이 없었기 때문이다.

종합하자면, 체육진흥투표권에 대한 체육 예산의 의존 도는 점점 높아지는 반면, 정부의 체육 예산 지원 비중은 꾸준히 낮아지는 모습을 띠고 있다. 이에 따라 체육진흥 투표권 수익금이 체육 예산의 역할을 대신하게 되었으나. 동시에 실시되고 있는 매출총량제의 존재는 체육 예산의 원활한 조성에 걸림돌이 될 수밖에 없는 환경을 만들어 냈다. 예산 명목으로 사용되고 있는 투표권 사업 수익금 의 사용에 대한 정부의 관리 수준 또한 비교적 미흡한 것 으로 보인다.

\section{논의}

본 연구는 합법 사행산업으로서 현재 체육진흥투표권 정책이 가지는 한계를 불법 스포츠도박의 횡행과 체육 예 산 의존도를 중심으로 살펴보았다. 체육진흥투표권은 본 질적으로 경제적 효과, 스포츠 발전 기금 조성, 사행욕구 해소, 여가 기능 등의 순기능과 사행심 조장, 스포츠도박 중독, 개인 파멸 등의 역기능을 모두 지니고 있다. 그러나 현재 운영 정책상의 한계로 인해 순기능은 약화되는 반 면, 역기능은 심화되는 양상이 나타나고 있다.

체육진흥투표권은 정부 규제에 따른 부족한 경쟁력으

2) 국민체육진흥기금으로부터 지원금을 받는 주최단체와 방송사 간에 일종의 리베이트 거래가 성립된 것으로 볼 수 있다. 
로 인해 오히려 불법 스포츠도박 문제를 심화시키고 있다 고 지적받고 있다. 사업 경쟁력 문제는 낮은 환급률 등의 금전적 측면과 불편한 베팅 환경, 상품의 다양성 결여 등 의 비금전적 측면에서 모두 나타나며, 이는 결국 사행산 업 매출총량제 적용에 따른 부작용으로 귀결된다. 체육진 흥투표권의 베팅 편의성을 개선하고 상품의 다양성을 제 고한다면, 증가한 매출을 통해 환급률의 상승 또한 자연 스럽게 이루어질 수 있다. 그러나 매출총량제의 존재는 이러한 시도들을 원천적으로 봉쇄하고 있으며, 참가자들 이 불법 스포츠도박에 대한 선호도를 높이는 데 일조하고 있다. 이는 합법 사행산업에 대한 규제가 불법 사행산업 으로의 유입을 팽창시킨다는 '풍선효과’가 그대로 드러난 것으로 볼 수 있다(Seo \& Lee, 2013).

여기에 더해 체육진흥투표권의 체육 예산 활용을 둘러 싼 모순적인 정책 구조 또한 문제가 되고 있다. 체육 예산 에서 투표권 사업 수익금이 차지하는 비중은 꾸준히 증가 한 반면, 국고 비중은 지속적으로 감소해 왔다. 이는 2003년부터 2007년까지의 정부 총예산과 체육 예산의 비교를 통해 정부 예산은 계속 증가한 반면 체육 예산은 감소하거나 제자리에 머물렀음을 지적한 $\mathrm{Kim} \&$ $\operatorname{Kim}(2009)$ 의 연구 결과의 연장선에 있다. 투표권 사업 을 통한 공공재정 기여라는 측면에서 이는 분명 합당하 다. 그러나 정부의 매출총량제 실시는 체육진흥투표권의 성장을 가로막음으로써 이러한 재정적 효과를 약화시킴 은 물론, 체육 예산 기여라는 투표권 사업 운영에 대한 정 책 목표와도 모순되는 모습을 띠고 있다.

마지막으로, 체육진흥투표권의 수익금을 분배받는 종 목별 주최 단체의 기금 집행에 대한 정책 방향성이 전무 하다. 현재의 체육 예산 구조상 투표권 사업 수익금은 공 공 예산의 성격이 짙으며, 예산은 그 특성상 사용 내역에 대해 충분한 논의를 통한 사회적 합의가 반드시 뒤따라야 한다. 국민체육진흥기금이 공익기금으로서 지속적인 체 육 발전을 위해 사용되려면 국민들의 지지가 필요하며, 여기에는 기금 사용에 대한 공공성과 건전성, 투명성이 반드시 전제되어야만 한다(Son, 2012). 특히 프로스포 츠 및 아마추어 스포츠 단체들은 체육 예산의 형태로 국 민체육진흥기금을 지원받는 만큼, 사용처에 대한 정부의 정책적 가이드라인이 반드시 동반되어야만 한다.

\section{결론}

논의에서 드러난 모든 문제점들을 고려할 때, 본 연구 는 체육진흥투표권과 그 수익금의 운영 정책 및 제도에 대해 세 가지 개선 방안을 제언한다.

첫 번째는 비금전적 차원에서의 규제 완화이다. 불법 스포츠도박의 참가 동기에 대한 대부분의 선행연구들은 참가자들이 환급률 등 금전적 요인보다는 베팅 편의성과 상품 다양성 등 비금전적 요인에 의해 불법 스포츠도박을 선택한다고 밝혔다. 따라서 규제 완화를 통해 체육진흥투 표권이 베팅 환경을 개선하고 다양한 상품들을 제공할 수 있도록 허용하여 불법 스포츠도박에 대한 수요를 합법으 로 유도해야 한다. 베팅의 편의성을 위해서는 스마트폰 및 모바일 어플리케이션 베팅 환경 제공, 단일 경기 베팅 허용, 24 시간 발매 및 환급 허용 등이 고려될 수 있다. 상 품의 다양화를 위해서는 첫 삼진이나 첫 3점슛 등 비교적 단순한 방식의 베팅 상품 추가가 검토될 수 있다. 이러한 유형의 상품들은 이미 해외의 수많은 스포츠도박 업체들 에 의해 제공되고 있으며, 베팅의 단순성과 즉흥성을 통 해 많은 수요자들을 끌어들이고 있다.

두 번째는 체육 예산에 대한 정부 정책의 명확한 방향 성 확립이다. 현재 정부는 체육 예산에 대한 국고 지원을 줄이며 그 역할을 체육진흥투표권에 떠넘기는 동시에, 매 출총량제 시행을 통해 체육 예산 조성을 스스로 방해하는 모순적인 모습을 보이고 있다. 따라서 체육진흥투표권의 공익적 기능을 중요시한다면 이러한 사회적 기여가 극대 화될 수 있도록 투표권 사업에 한한 매출총량제 완화를 고려하여야 한다. 만약 합법 사행산업인 체육진흥투표권 의 지나친 사행성이 우려된다면, 정부는 투표권 사업에 대한 체육 예산 의존도를 줄이는 한편 체육 예산에 대한 국고 지원 비중을 끌어올려야 할 것이다. 현재 체육진흥 투표권 및 체육 예산을 둘러싼 정책들이 모순적인 행태를 보임으로써 체육 예산 극대화와 사행성 완화 중 그 어떤 정책 목표도 확실하게 이루지 못하고 있는 만큼, 이 부분 에 있어 정책의 통일성이 요구되고 있다. 물론, 체육 예산 극대화와 체육진흥투표권의 사행성 완화 중 어느 쪽이 공 익에 기여하는 가에 대해서는 후속 연구가 필요할 것이다.

세 번째는 체육진흥투표권 수익금을 분배받는 단체의 기금 집행에 대한 제도적 관리의 도입이다. 투표권 사업 
으로 조성된 국민체육진흥기금이 사실상 체육 예산의 형 태로 다양한 체육 단체들에게 지원되고 있으나, 이들의 사용을 관리하는 지침은 형식적인 정도에 그치고 있다. 예산의 성격이 짙은 이상, 각 체육 단체들이 집행하는 기 금에는 정부의 체육 정책과 맥락을 함께 하는 가이드라인 이 제시되어야 할 것이다. 예를 들어, 정부가 정책 기조로 생활체육 활성화를 추구한다면 프로 및 아마추어 운동경 기 주최단체들은 이에 맞추어 각 종목의 생활체육화를 위 해 지원 기금을 일정 비중 투자하도록 권고하는 방안이 있을 수 있다.

\section{참고문헌}

Cho, H. C. (2019, April 11). Annual fundraising of 1,000 billion KRW...'Health guardian of people' Korean Sports Promotion Foundation. The Korea Economic Daily. Retrieved from https://www.hankyung.com/sports/article/2019041136601

Choi, M. K. (2016, August 22). Professional baseball match fixing, rooted in government's monopoly of sports betting industry? Economist. Retrieved from http://jmagazine.joins.com/economist/view/312764

Chungbuk National University. (2016). The 3rd Factual Investigation of Illegal Gambling. National Gambling Control Commission.

Gainsbury, S. M.. (2010). Gambling on the Olympics: Editorial. International Gambling Studies, 10(1), 1-4.

Han, S. K., Kang, W. C. (2012). The Actual Condition and Countermeasure of Illegal Sports Gambling. Parliamentary office of Han Sun-Kyo.

Holden, J. T. (2019). Prohibitive Failure: The Demise of the Ban on Sports Betting. Georgia State University Law Review, 35(2).

Kang, S. K. (2015). Fundamental way to deal with illegal gambling. KIC ISSUE PAPER, 3, 1-21.

Kim, C. (2006). A Study on the College Students' Perceptions and Purchase Behavior of the Sports Toto. Korean Journal of Sport Management, 11(4), 33-45.

Kim, H. M. \& Kim. H. K. (2009). A Study On the Budget Management in Physical Activity Policies of the Participatory Government. Korean Journal of Sports Science, 18(3) 17-30. Kim, H. (2015). The status of illegal sportstoto and the search for its solutions. Korean Journal of Sports Science, 24(5), 81-98.

Kim, J. K. (2015). Study on the Regulatory Policy in Korea Gambling Industry. Korean Association for Public Administration Collected Papers, 2015(12), 2864-2879.

Kim, K. M. (2015, May 8). Ground wave broadcaster trio, still neglect to broadcast after getting paid 1.5 billion KRW... professional soccer is sad. Hankyoreh. Retrieved from http://www.hani.co.kr/arti/society/media/690399.html

Kim, N. H., Park, S. U., \& Jeon, J. W. (2015). An Exploration into the College Students' Adherence Behavior of Illegal Sports Gambling. Korean Journal of Physical Education, 54(6), 95-105

Kim, S. Y., \& Oh, J. S. (2017). A Survey on the Illegal Sport Gambling of Male Middle and High School Students. Korean Journal of Sports Science, 26(3), 23-39.

Korea Industrial Development Institute. (2011). Research on plan to set efficient revenue cap regulation in gambling industry. National Gambling Control Commission.

Kwon, K. N., \& Lee, J. R. (2018). AStudy on Participation of Illegal Sport Gambling by the Korean School Elite Sports Athletes. Korean Journal of Physical Education, 57(6), 11-24.

Lee, C. K. (2008). Estimating the Economic Impact of Sports-toto Industry: using an Input-Output Model. Korean Journal of Sport Management, 13(3), 53-63.

Lee, H. W. (2012, September 11). If gambling is a problem, why does government allow 'Legal Gambling'?. Pressian. Retrieved from http://www.pressian.com/news/article/?no=21257

Lee, J. L., \& Hong, J. Y. (2017). The Reasons behind Selecting Illegal Sports-ToTo, and Exploring the Empirical Meanings. Korean Journal of Physical Education, 56(5), 131-145.

Lee, J. Y., \& Jo, W. Y. (2016). Current State and Improvement Method of Sport Betting Industry. Korean Sociological Association Sociology Competition Collected Papers, 2016(6), 77-88.

Lee, S. P. (2018, November 4). Flourishing illegal sports gambling, venom to the growth of professional sports industry. Joynews24. Retrieved from http://www.joynews24.com/view/1137733

Lee, Y. H., Cho, T. H., Bae, Y. M., \& Park, Y. H. (2018). Does Legalized Gambling Industry Substitute Illegal Gambling?: A Case Study on Sports Betting. Journal of International Trade \& Commerce, 14(1), 303-319. 
Lim, T. S., Lee, H. Y., \& Kim, J. Y. (2014). An Analysis the Differences of Illegal Sports-Toto Gambling Participants' Participation Behaviors and Willingness to Change to Legal Sports-Toto Gambling Participation According to the Level of Gambling Addition. Korean Journal of Physical Education, 53(2), 469-483.

Moon, C. E. (2016, January 22). Our stance for private sports gambling. Herald corporation. Retrieved from http://news.heraldcorp.com/sports/view.php?ud=2016012217 25380812389_1

Park, S. H. (2019). Problems of Illegal Sports Gambling and Measures to Eradicate it in Korea. The Journal of Sports and Entertainment Law, 22(1), 3-25.

National Gambling Control Commission. (2008). Comprehensive Plan for Sound Development of Gambling Industry. National Gambling Control Commission.

National Gambling Control Commission. (2010). Statistics Regarding Gambling Industry: Year 2009. National Gambling Control Commission.

National Gambling Control Commission. (2019). Statistics Regarding Gambling Industry: Year 2018. National Gambling Control Commission.

Oh, S. I., Lee, M. S., Kang, S. J., \& Choi, Y. (2019). The Effect of Stress Coping Style on Cycle Racing Participate Motive:
Based on the Mediating Effects of the Daily Stress. The Journal of Humanities and Social science, 10(2), 1035-1049.

Oh, S. Y. (2018). A Study on Countermeasure and Second Crime Caused by Juvenile Internet Gambling Addiction. Korea Criminal Intelligence Review, 4(1), 79-95.

Reith, G. (2002). The Age of Chance: Gambling and Western Culture. London: Routledge.

Seo, W. S., \& Lee, M. J. (2013). Research Articles: A Study on Gambling Policy Focusing on Investigation of Legal and Illegal Gambling Participants’ Behavior and Relation between Legal and Illegal Gambling. Journal of Tourism Sciences, 37(8), 97-119.

Son, S. J. (2012). Legal issues of Sports Toto's business. The Korean Association of Sports Law, 15(4), 37-58.

Vacek, H. (2011). The History of Gambling. Center for Christian Ehtics at Baylor University.

Yoon, S. C. (2018). Status of illegal sports betting and Applicable Law. Legislation, 2018(2), 101-123.

Yun, W. S. (2016) Study about Operation Methods of Unlawful Internet Gambling: Suggesting A New Research Method by Using Observation Survey. Korean Academy of Public Safety and Criminal Justice, 25(3), 139-165. 


\title{
체육진흥투표권 사업에 대한 정책적 한계: 불법 스포츠도박과 체육 예산 문제를 중심으로
}

\author{
전택수 \\ 한양대학교, 학사
}

[목적〕 본 연구는 합법 사행산업인 체육진흥투표권의 운영에 대한 정책적 한계를 불법 스포츠도박과 체육 예산 문제 차원에서 분석하였다. 〔방법) 연구방법으로는 문헌 연구법을 채택하였으며, 연구 자료의 수집은 문화체육관광부, 사행산업통합감독위원회, 국민체육진흥공단 등이 발행한 보고서 및 통계자료, 그리고 기존 선행연구를 통해 이루어졌다. 〔결과〕체육진흥투표권은 불편한 베팅 환경, 상품의 다양성 결여, 낮은 환급률 등이 지적되고 있으며, 이로 인해 불법 스포츠도박이 더욱 확산되고 있다고 비판받고 있다. 여기에 체육 예산 에 대한 국고 지원 비중이 감소한 반면, 매출총량제의 시행은 투표권 사업의 성장을 억제하여 체육 예산 조성 을 방해하는 정책적 모순이 나타나고 있다. 예산 기능을 수행하는 체육진흥투표권 수익금의 사용에 관한 명확 한 지침 또한 존재하지 않는다. 〔결론) 본 연구는 이러한 문제의 해결을 위해 체육진흥투표권과 그 수익금의 운영에 대해 정책적, 제도적 차원에서 세 가지 개선 방안을 제시하였다. 첫 번째는 비금전적 차원에서의 규제 완화로, 체육진흥투표권이 베팅 편의성과 상품 다양성을 개선할 수 있도록 허용하여 불법 스포츠도박에 대한 대체 효과를 끌어올려야 한다. 두 번째는 체육 예산에 대한 정부 정책의 명확한 방향성 확립으로, 체육진흥투 표권의 체육 예산 활용과 사행성 완화 중 하나의 통일된 정책 기조를 택하여 정책 효과를 극대화하여야 한다. 세 번째는 체육진흥투표권 수익금을 지원받는 단체들의 기금 집행에 대한 제도적 관리의 도입으로, 예산의 집 행이 정부의 체육 정책 방향과 부합하도록 하여야 한다.

주요어: 체육진흥투표권, 스포츠도박, 불법, 예산, 매출총량제 